\title{
Opprettelsen av etiske komiteer for medisinsk forskning
}

Engelsk oversettelse på www.tidsskriftet.no

\begin{abstract}
Sammendrag
Bakgrunn. I denne artikkelen redegjør vi for prosessen som ledet frem til opprettelsen av regionale forskningsetiske komiteer i medisin i 1985. Vi ser også på den trange starten for komiteene i region øst og $s ø$.
\end{abstract}

Materiale og metode. Vi har undersøkt materialet som er avgitt til Riksarkivet fra Norges allmennvitenskapelige forskningsråd, Sosialdepartementet, Kultur-og vitenskapsdepartementet og arkivet til Regionale komiteer for medisinsk og helsefaglig forskningsetikk sør-øst.

Resultater. Legeforeningen spilte en sentral rolle fra tidlig i 1970-årene, bl.a. for forslaget om «landsdelskomiteer» i 1977. Det var bred enighet om at det var et ønske om slike komiteer, men alle forutsatte at noen andre skulle finansiere dem. Det medførte at den enkleste modellen ble valgt. Samtlige regionale komiteer var først på plass i 1987, og det tok enda lenger tid før de fikk et budsjett for å sikre forsvarlig saksbehandling. Det skjedde først med forskningsetikkloven i 2006.

Fortolkning. Uavklarte økonomiske spørsmål var den viktigste årsaken til at prosessen tok så lang tid. Organiseringen som Legeforeningen foreslo i 1977, er omtrent den samme som kom på plass med helseforskningsloven i 2009.

\section{Emil Lahlum}

emil.lahlum@medisin.uio.no

Knut W. Ruyter

Regionale komiteer for medisinsk og helsefaglig forskningsetikk sør-øst

Oslo

Forskningsetiske komiteer ble opprettet fra midten av 1960-tallet i bl.a. USA som et mottiltak mot uetisk forskning. Man erkjente at det ikke er tilstrekkelig at vurderinger foretas av forskere selv (1). Slik var det ikke i Norge. Den umiddelbare bakgrunnen for at spørsmål om opprettelse av forskningsetiske komiteer kom opp, var anbefalingen gitt i Helsinki-deklarasjonen av 1975 om at «ethvert eksperiment som omfatter mennesker (...) skal forelegges en spesielt oppnevnt uavhengig komite til gjennomgåelse, uttalelse og veiledning» (2). De drivende aktørene for å få det til var Rådet for legeetikk, dets leder Erik Enger (f. 1927), og Rådet for medisinsk forskning (RMF) under Norges allmennvitenskapelige forskningsråd (NAVF).

Rådet for medisinsk forskning avholdt flere store seminarer, første gang i november 1976, som førte til at Legeforeningen i brev av 26.5. 1977 fremmet et konkret forslag om å opprette komiteer for forskningsetikk (3). Som Erik Enger tydelig formulerte det: «Den reviderte deklarasjonen innebærer at tiden nå er inne også i vårt land til å diskutere spørsmål om å opprette slike komiteer og spørsmålet om deres funksjon.» (4)

\section{Materiale og metode}

Vi har undersøkt det materialet som er avgitt til Riksarkivet fra Norges allmennvitenskapelige forskningsråd, Sosialdepartementet og Kultur- og vitenskapsdepartementet. Arkivet til Regionale komiteer for medisinsk og helsefaglig forskningsetikk (REK) sør-øst inneholder korrespondanse med departementer, Legeforeningen og Universitetet i Oslo, i tillegg til et fullstendig arkiv over alle prosjekter som er blitt behandlet fra 1987. Prosjekter som ble behandlet av etikkutvalget under Rådet for medisinsk forskning fra 1978 er avlevert til Riksarkivet.

\section{Forpostfektninger før 1977}

Selv om tiden var inne først i 1977 viste initiativ og interesse for forskningsetikk at grunnen var godt forberedt. Etter initiativ fra de nordiske legeforeningene og forskningsrådene ble det i 1973 nedsatt en nordisk arbeidsgruppe, bestående av Erik Enger, Clarence Blomquist (1925-79) og Povl Riis (f. 1925). Gruppen skulle fremme forslag til en revidert Helsinki-deklarasjon. Den fremmet bl.a. forslag om at forsøksprotokoller skulle forelegges en uavhengig etisk komité $(3,5)$.

I et notat fra Rådet for medisinsk forskning om etiske komiteer fra 2.11. 1977 fremgår det at saken var blitt satt på dagsorden i 1974 for å få etablert «etiske regler for medisinsk forskning» (3). Rådet for medisinsk forskning skjelte til Sverige, som etter mønster fra USA hadde opprettet institusjonelle forskningsetiske komiteer i 1966. Noen slike institusjonelle etikkomiteer ble også opprettet i Norge (5).

Planlegging og opprettelse 1976-85 Møtet i Rådet for legeetikk 6.11. 1976 markerte begynnelsen på arbeidet for opprettelsen av etiske komiteer i Norge (3). Myndighetene var også interessert (6). Det ble nedsatt en arbeidsgruppe for å utarbeide et mer konkret forslag. Arbeidsgruppen besto av representanter fra Helsedirektoratet og Norske Kommuners Sentralforbund, i tillegg til legene Egil Gjone (1925-99) og Erik Enger, og advokat Åsmund Hodne (f. 1940) (3).

For å avgjøre hvordan dette best kunne ivaretas i Norge var arbeidsgruppen særlig interessert i å se på hvilken modell som var blitt brukt i Danmark. Den danske modellen innebar regionale komiteer med en overhengende nasjonal komité. Disse komiteene skulle være bredt sammensatt, og det var på dette tidspunktet en forestilling om at de skulle bestå av fire leger, to legmenn og en sykepleier. Den norske modellen ble i høy grad basert på dette, og arbeidsgruppen fremmet et forslag som innebar et system med tre nivåer for etisk godkjenning (fig 1).

\section{Hovedbudskap}

- I 1976 startet arbeidet for opprettelsen av etiske komiteer i Norge

- I 1987 var alle regionale etiske komiteer i funksjon

- I 2006 fikk komiteene øremerkede midler til forsvarlig drift 
På det laveste nivået mente gruppen at det burde opprettes lokale etikkomiteer ved sykehusene. Disse skulle være rådgivende, og funksjonsområdet skulle være å vurdere etiske aspekter ved forskningsprosjekter som skulle utføres ved det aktuelle sykehuset.

Neste nivå var det som ble kalt overordnede etikkomiteer. Disse, foreslo gruppen, skulle tillegges besluttende myndighet. Funksjonsområdet for disse komiteene skulle være å avgjøre tvilstilfeller fra de lokale komiteene og fungere som en type klageinstans for forskeren dersom han/hun var misfornøyd med behandlingen i den lokale etikkomiteen. Arbeidsgruppen utbroderte videre $i$ et brev fra 1977 at «disse organ i tillegg til medisinsk forskning i snevrere forstand bør påta seg å vurdere veterinær-medisinsk forskning, odontologisk forskning, sosiologisk forskning og annen forskning som angår mennesker» (3).

De overordnede etikkomiteene skulle videre deles inn geografisk, og de ble derfor også kalt landsdelskomiteer. Den geografiske inndelingen innebar en komité i regionene Sør-Norge, Vest-Norge, Midt-Norge og Nord-Norge. Sammensetningen av komiteene skulle være to representanter fra universitetene, en sykehuseier, en fra Norges allmennvitenskapelige forskningsråd, en sykehuslege, en fra offentlig myndighet og en legmann. Endelig skulle det opprettes en nasjonal klageinstans for landsdelskomiteene.

Skepsisen var klar til hvorvidt det var behov for en så ambisiøs organisering. Fra saksdokumenter i Sosialdepartementet er det påtegnet en rekke forbehold i margen (3). I ett av dem fra 6.6. 1977 står det at «dette blir for infløkt» med anbefaling om at «vi bør vel få en enklere løsning» (3). I brev fra Sosialdepartementet til Legeforeningen 7.10. 1977 anbefalte departementet at man først utprøver «en enklest mulig modell» (3). Og slik ble det.

\section{Enklest mulig modell}

Etter forslag fra Legeforeningen i brev av 21.7. 1978 opprettet Forskningsrådet et eget etikkutvalg under Rådet for medisinsk forskning (5). Det ble foreslått at utvalget også skulle bestå av «eksterne», dvs. andre enn leger. Rådet for medisinsk forskning oppnevnte utvalget i påvente av at det formelt skulle opprettes «en sentral komite» og for å kunne ivareta forpliktelsen med forhåndsvurdering fra en uavhengig forskningsetisk komité i henhold til Helsinki-deklarasjonen fra 1975. Rådet for medisinsk forskning utarbeidet mandat og skjema for å dekke «all forskning som angår menneskets helse (klinisk medisin, odontologi og sosialmedisin, eksperimentell medisin, osv.)» (5). Den første komiteen besto av professor Jarle Ofstad (f. 1927), som var formann, professor Egil Gjone på Rikshospitalet, helsedirektør Torbjørn Mork (1928-92) og de «eksterne» - byråsjef Ingse Stabel

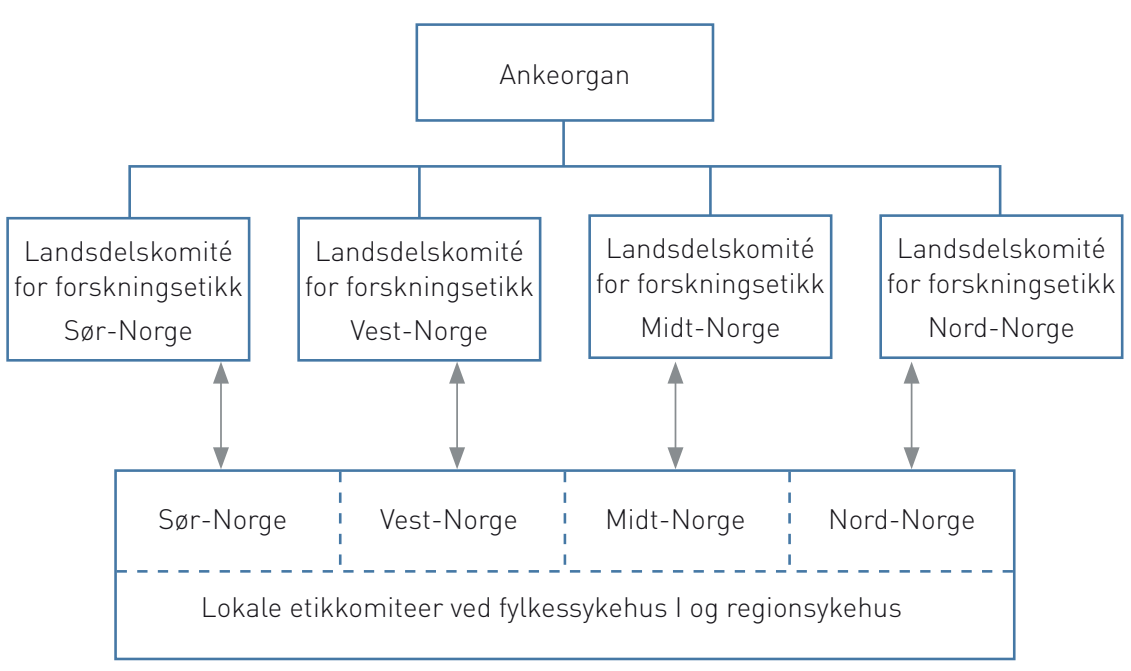

Figur 1 Den norske modellen ble i høy grad basert på den danske modellen, som innebar et system med tre nivåer for etisk godkjenning

(f. 1946) i Justisdepartementet og professor Jacob Jervell (f. 1925) fra Det teologiske fakultet, Universitetet i Oslo. Det første møtet ble holdt 14.9. 1979 (5).

\section{Arbeidet stoppet nesten opp}

Med opprettelsen av utvalget under Rådet for medisinsk forskning var forpliktelsen til en ordning med forhåndsgodkjenning løst. Det var nok i seg selv også en årsak til at saken mistet fremdrift.

I tillegg hadde de største sykehusene opprettet egne lokale komiteer. Den fremste pådriveren for etablering av etikkomiteer i Norge, Erik Enger, ledet den lokale komiteen ved Ullevål sykehus. Han uttalte i forbindelse med planer for opprettelse av nye lokale komiteer ved sykehusene at det «innebærer jo i praksis at det sannsynligvis ikke blir noe av de regionale komiteer i det hele tatt» (7). Det mente også Hans Erik Rugstad (f. 1935), den senere lederen av REK sør-øst: «Arbeidet med regionale etiske komiteer synes å ha stoppet opp.» (8)

I en oppsummering om arbeidet med opprettelsen av regionale etiske komiteer fra Sosialdepartementet til Kirke- og undervisningsdepartementet i januar 1981, fremkom det imidlertid at det var den manglende avklaringen av økonomiske forhold som var avgjørende fremfor behov og omfang (9). Det var også uenighet om organisering, behov for sekretariat og møtegodtgjørelse for medlemmer. Departementet anså imidlertid Norges allmennvitenskapelige forskningsråds forslag om at sekretariatene burde «ivaretas» av de medisinske fakultetene i de respektive regionene «som en naturlig løsning» (9). Og slik ble det også, til slutt.

En av de viktigste grunnene til at kvernen malte langsomt videre var den rapporten som et utvalg under hovedkomiteen for norsk forskning avleverte høsten 1981 om forskning og etisk ansvar, under ledelse av filosofiprofessor Knut Erik Tranøy
(1918-2012) (10). I rapporten beklaget man seg over at Norge «er det land i Norden som ligger lengst etter med hensyn til opprettelse av forskningsetiske komiteer for biomedisinsk forskning», og man anbefalte «på det sterkeste» at hovedkomiteen skulle be Regjeringen om at de foreslåtte ordningene «trer i kraft umiddelbart» (10).

Året etter, i Stortingets spørretime, etterspurte Grete Knudsen (f. 1940) «når statsråden kan love at komiteene blir opprettet» (11). Statsråd Lars Roar Langslet (f. 1936) meldte at universitetene hadde stilt seg positive til at sekretariatene ble lagt til de medisinske fakultetene, og at han regnet med at «Sosialdepartementet vil støtte tiltaket med dekning av driftsutgifter». Fra eget departement regnet han med at «vi en av de aller nærmeste dager vil finne frem til en ordning for sekretariatsfunksjonen». Men slik gikk det ikke.

\section{Første funksjonsperiode 1985-89 i sør og øst}

Det ble oppnevnt medlemmer til fem regionale komiteer for medisinsk forskningsetikk fra 1.7. 1985 (12). Hver komité skulle ha sju medlemmer med vararepresentanter. Disse var representanter fra medisinsk fakultet, sykehuseier, helsemyndighet og Sykepleierforbundet, i tillegg til representanter med etikkompetanse og dommerkompetanse og legepresentasjon.

Første periode for komiteene i region sør og øst skulle vise seg å bli vanskelig. Mens de andre regionene iverksatte sitt arbeid relativt kort tid etter oppnevnelsen, skulle det drøye helt til høsten 1987 før regionene i sør og øst avholdt sine første møter.

Hovedproblemet med oppstarten dreide seg om økonomi. Der hvor de andre regionene raskt fikk på plass en halv sekretær per komité, måtte sør- og østregionene greie seg med en halv stilling på deling (13). Selv om Langslet hadde regnet med støtte fra 


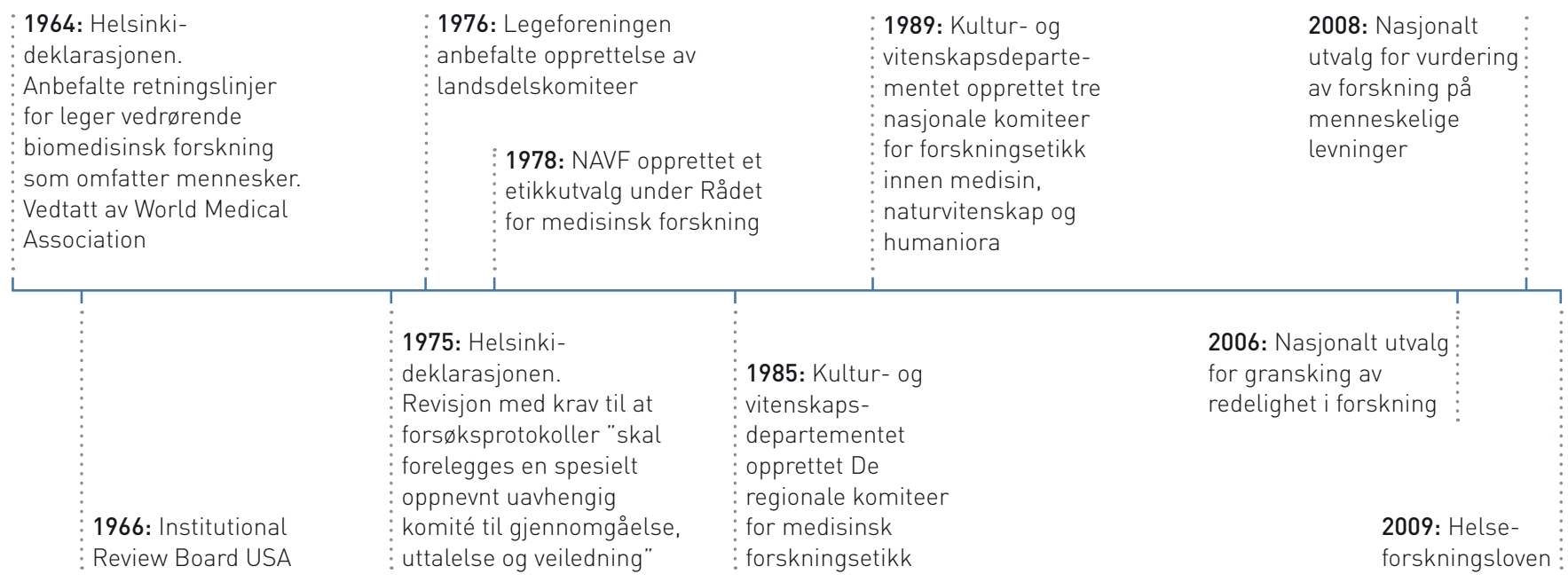

Figur 2 Denne tidslinjen viser noen milepæler frem til helseforskningsloven i 2009

Sosialdepartementet, og universitetene var positive, var det ikke avklart hvem som var forventet å dekke utgiftene. Universitetet i Oslo kan ikke sies å ha vært på tilbudssiden. Uklarheter gjorde det også vanskelig å rekruttere ledere til komiteene, da kandidatene til vervet bekymret seg for arbeidsmengden de ville få ettersom sekretærhjelpen ville være svært beskjeden. Dette ble spesielt tydelig da begge de oppnevnte formennene for region sør og øst trakk seg før det i det hele tatt var avholdt ett eneste møte. Selv om årsakene til dette langt på vei skyldtes økonomi, var det implikasjonene som var selve hovedproblemet. Olav Hilmar Iversen (1923-97) og Erik Enger uttalte i et intervju med Aftenposten 24.10. 1986: «Spørsmålene komiteene skal ta stilling til, angår menneskers liv og rettigheter og medisinens fremskritt og er ikke egnet som venstrehåndsarbeid.» (14)

Formennene for de to komiteene lot seg erstatte, men de økonomiske problemene vedvarte. Midlene satt svært langt inne i Kultur- og vitenskapsdepartementet, selv om det ble gitt midler til en halv konsulentstilling i mai 1986 (15). Evnen eller viljen var ikke mye større på Det medisinske fakultet som skulle sikre «infrastruktur» for komiteenes arbeid. I et skarpt brev til Kultur- og vitenskapsdepartementet i november 1987 la Tore Wie (f. 1944), den første sekretæren i REK sør, ikke mye mellom: «Alle vet at den økonomiske rammen for komiteene er meget trang. For denne komité er dette ytterligere aksentuert ved at Rikshospitalet, som husvert, har avslått all økonomisk støtte til den fysiske etableringen bortsett fra å stille et nakent, bortgjemt og helt nedslitt kontor til disposisjon. Ikke engang det elektriske opplegg er adekvat for vårt behov.» (13)

\section{De første møtene i sør og øst}

Til tross for bortgjemt plass og skrinne arbeidsvilkår, fant de første møtene sted høsten 1987. REK øst var først ute med sitt konstituerende møte 16.9., mens REK sør fulgte etter 11.12. (16). Det var flere utfordringer som møtte komiteene i første periode. I REK sørs årsrapport fra 1988, altså komiteens hele første virkeår, peker man på flere av disse (13). Igjen var budsjett et hovedproblem. Det begrensede budsjettet medførte at komiteen måtte ha et redusert antall møter. For 1988 ble resultatet av dette seks vanlige møter, i tillegg til ett ekstraordinært møte. Det totale antallet nye søknader for året var 111. Ifølge årsmeldingen medførte den store saksmengden «flere maratonmøter med en uendelighet av saker på dagsorden».

I mars 1988 skrev den nye lederen av REK sør, professor Hans Erik Rugstad, et meget bydende brev til dekanus ved Det medisinske fakultet om «komiteens økonomi og livskraft». Han minnet om at det bare var «med et nødskrik at denne komité overhodet kom i gang» og ramset opp tomt kontorlokale på loftet, intet budsjett og en uholdbar arbeidssituasjon for sekretær og komité. Hvis strakstiltak ikke ble iverksatt, bebudet Rugstad at «komiteen står foran et totalt havari med nedleggelse som resultat» (14). Det virket. Fra 1.7. ble veterinær Tore Wie ansatt i hel stilling for REK sør (13), et budsjett kom på plass, og infrastrukturen ble forbedret.

Men det var også tid til innholdsmessige betraktninger. I et møtereferat nevner man for eksempel at flere mente at den norske oversettelsen av Helsinki-deklarasjonen var for streng. Jon Wetlesen (f. 1940), etikkyndig medlem av komiteen, var særlig opptatt av at retningslinjene var blitt til regler gjennom bruk av «skal» og «må», mens det burde være «bør» (17).

\section{De første prosjektene}

Årsrapporten fra REK sør fra 1988 gir en god indikasjon på hvilke typer prosjekter som ble fremlagt og vurdert (13). Nesten
$80 \%$ av prosjektene dreide seg om kliniske utprøvninger av legemidler, ca. $15 \%$ om epidemiologi. Det er verdt å merke seg at klinisk forskning var ubetydelig og at prosjekter fra andre forskere enn leger var helt fraværende, selv om komiteen hadde representasjon fra sykepleiefaget.

De første kliniske utprøvningene som ble fremlagt, dreide seg om mild til moderat hypertensjon, alvorlige infeksjoner, revmatoid artritt og alvorlig hjertesvikt. Komiteen var i alle tilfeller mest opptatt av spørsmål om tilfredsstillende forsikring, som måtte bekreftes av sponsor. Det har sin forklaring i at lov om produktansvar først trådte i kraft 1.1. 1989. I ett tilfelle satte komiteen vilkår for sikring av persondata før de ble utlevert til utlandet og foretok mindre rettelser $\mathrm{i}$ informasjonsskrivet. Det var ingen vurderinger av design, placebo eller risiko og nytte.

Blant andre typer forskning kan nevnes diettutprøving ved infantil autisme og krybbedød. I diettutprøvingsprosjektet ble det krevd en fyldig pasientinformasjon som samsvarte med Helsinki-deklarasjonen. Men komiteen reiste også faglige innvendinger mot protokollen, bl.a. at den ikke skulle karakterisere pasienten biokjemisk ved analyse av urin og serum for å klarlegge peptidmønsteret, da prosjektleder hadde begrunnet forsøket med sammenhengen mellom peptidmønstre i serum og urin og psykisk tilstand. Til tross for faglige innvendinger fra komiteen ble prosjektet godkjent.

I prosjektet om krybbedød, som skulle gjennomføres av en medisinstudent, ville man gjøre målinger av eksogene og endogene opioider ved hjelp av radioimmunoassay i spinalvæske, corpus vitreum og serum og ved hjelp av sandwichteknikk til snitt i hjernestammen. I prosjektet ville man også intervjue berørte familier, bl.a. om matinntak og stressfaktorer før hendelsen. Komiteen hadde ingen innvendinger til analyser av biologisk materiale, men den godtok ikke den retrospektive intervju- 
undersøkelsen. Den fremholdt at det «vil kunne skape ny bekymring og selvbebreidelse hos allerede hardt belastede foreldre». Dette hensynet kunne likevel tilsidesettes hvis nyttige resultater kunne sannsynliggjøres. Det ble også anført at et «slikt følsomt og vanskelig intervjuarbeid neppe (vil) være egnet som et studentprosjekt siden foreldrene åpenbart vil ha behov for hjelp og støtte som krever både stor innsikt og erfaring». Dette var komiteens første avslag, og det er interessant at komiteens sekretær tilføyde «for egen del» at det i vedtaket «ikke ligger noen form for mistillit til deg som person eller dine faglige kvaliteter (...) Det har kun med ømtålige og vanskelige tema å gjøre. Vi håper derfor at du senere vil komme sterkt igjen og at dette lille «tilbakeslag» bare vil virke ansporende for fornyet innsats».

\section{Konklusjon}

Sett i ettertid er det interessant at det, til tross for bred enighet om å etablere de regionale komiteene for medisinsk forskningsetikk, var uavklarte spørsmål om hvem som skulle betale for hva. Det var den viktigste årsaken til at det tok så lang tid. Først med forskningsetikkloven i 2006 fikk REK øremerkede midler til forsvarlig drift. Figur 2 viser noen høydepunkter i utviklingen.

Det er også interessant at den organiseringen Legeforeningen opprinnelig utarbeidet i 1977 (fig 1), så godt som er den samme som falt på plass med helseforskningsloven i 2009. Den var klartenkt og forutseende. Selv om vi i dag ikke har lokale etiske komiteer i den forstand som var tenkt den gangen, fremholder helseforskningsloven forskningsinstitusjonenes selvsten- dige ansvar for å organisere og kvalitetssikre forskning på en forsvarlig måte. Det fører til opprettelse av lokale etiske komiteer, selv om de går under andre navn, som forskningsstøtteavdeling, forskningsetisk utvalg o.1.

Fra en nokså beskjeden og haltende begynnelse er REK $\mathrm{i}$ dag en profesjonell organisasjon som forvalter helseforskningsloven og vurderer ca. 1800 nye søknader per år, med sju komiteer med 63 medlemmer og tilsvarende vararepresentanter, 26 ansatte i sekretariatene og med et budsjett på over 30 millioner kroner i året. Det hadde Erik Enger neppe forestilt seg da han i 1976 meldte at tiden var inne (4).

\section{Emil Lahlum (f. 1983)}

har mastergrad i historie og er ansatt som førstekonsulent ved Regionale komiteer for medisinsk og helsefaglig forskningsetikk sør-øst, Det medisinske fakultet, Universitetet i Oslo.

Forfatter har fylt ut ICMJE-skjemaet og oppgir ingen interessekonflikter.

\section{Knut W. Ruyter (f. 1955)}

er avdelingsdirektør ved Regionale komiteer for medisinsk og helsefaglig forskningsetikk $s ø r-\varnothing s t$, Det medisinske fakultet, Universitetet i Oslo. Han er dr. philos. og var etikkyndig medlem av REK øst 1993-2001. Fra 1996 til 2009 var han sekretariatsleder for Den nasjonale forskningsetiske komité for medisin.

Forfatter har fylt ut ICMJE-skjemaet og oppgir ingen interessekonflikter.
Litteratur

1. Katz J. Experimentation with human beings: the authority of the investigator, subject, professions and state in the human experimentation process. New York, NY: Russel Sage, 1972

2. Shepherd W, Enger E. Helsinki-deklarasjonen. Tidsskr Nor Lægeforen 1976; 96: 469-70.

3. Riksarkivet. Sosialdepartementet, Helsedirektoratet, Legekontoret, H1. Regionale komiteer for forskningsetikk 1970-1983.

4. Enger E. Helsinki-deklarasjonen - revidert forskningsetikk. Tidsskr Nor Laegeforen 1976; 96: 467-71.

5. Riksarkivet. NAVF. Rådet for medisinsk forskning. 63-arkiv. RMFS utvalg for forskningsetikk. $1974-1989$

6. St.meld. nr. 35 (1975-76). Om forskningens organisering og finansiering.

7. Brev fra Erik Enger til Egil Gjone 17.3.1982. REK sør-østs arkiv.

8. Brev fra Jacob Jervell og Hans Erik Rugstad til direktøren for Rikshospitalet 4.11.1981. REK sør$\emptyset$ sts arkiv.

9. Brev fra Sosialdepartementet 20.1.1981. REK sør$\emptyset$ sts arkiv.

10. Hovedkomiteen for norsk forskning. Forskning og etisk ansvar. En rapport fra utvalget for «Forskning og etikk» nedsatt av Hovedkomiteen for norsk forskning. Oslo: NAVF 1981

11. Forhandlinger i Stortinget 1982. Spørretime 8. desember, s. 1886

12. Riksarkivet. Kultur og vitenskapsdepartementet, Forskningsavdelingen, Infrastruktur spørsmål 1981-1986. Utviklingen av medisinsk etikk i Norge $1975-81$.

13. Arrsrapport 1988 for region 2. REK sør-østs arkiv.

14. Riksarkivet. Kultur- og vitenskapsdepartementet, Forskningsavdelingen, Infrastruktur spørsmål 1987-1988. Forskningsetikk - regionale etiske forskningskomiteer

15. Brev fra Kultur-og vitenskapsdepartementet til Det medisinske fakultets sekretariat ved Universitetet i Oslo 7.5.1986. REK sør-østs arkiv.

16. Dagsorden for REK sørs møte 11.12.1987. Referat fra REK østs møte 16.9.1987. REK sør-østs arkiv.

17. Wetlesen J. Helsinki-deklarasjonen - misvisende norsk oversettelse? Tidsskr Nor Legeforen 1989; 109: 1179-80.

Mottatt 14.3. 2012, første revisjon innsendt 2.4. 2012, godkjent 12.4. 2012. Medisinsk redaktør Erlend Hem. 